\title{
Cohort effect on discriminant rate: the case of greater flamingo (Phœnicopterus roseus) chicks sexed with morphological characters
}

\author{
Abdennour Boucheker ${ }^{1,2,3}$, Riad Nedjah $^{3}$, Roger Prodon $^{4}$, Mark Gillingham $^{2,5}$, \\ François-Xavier Dechaume-Moncharmont ${ }^{5,6}$, Arnaud Béchet ${ }^{2}$, and Boudjéma Samraoui ${ }^{1,3}$ \\ ${ }^{1}$ Biology Department, Badji Mokhtar University-Annaba, BP 12, Annaba, 23000, Algeria \\ ${ }^{2}$ Centre de recherche de la Tour du Valat, Le Sambuc, 13200 Arles, France \\ ${ }^{3}$ Laboratoire de Conservation des Zones Humides, Université 8 mai 1945, BP 401, Guelma 24000, Algeria \\ ${ }^{4}$ Centre d'Ecologie Fonctionnelle et Evolutive (UMR 5175), École Pratique des Hautes Études, Biogéographie \\ et Ecologie des Vertébrés, campus CNRS, 1919 route de Mende, 34293 Montpellier CEDEX 5, France \\ ${ }^{5}$ Institute of Experimental Ecology, University of Ulm, Albert-Einstein Allee 11, 89069 Ulm, Germany \\ ${ }^{6}$ Université Claude Bernard Lyon 1, CNRS, ENTPE, UMR 5023 LEHNA, 69622, Villeurbanne, France
}

Correspondence: Abdennour Boucheker (babdennour2007@yahoo.fr)

Received: 31 May 2020 - Revised: 6 October 2020 - Accepted: 15 October 2020 - Published: 25 November 2020

\begin{abstract}
We used a large dataset of greater flamingo chicks banded and measured at Camargue, France, to verify the applicability of discriminant function analysis to sex this species. Males and females sexed genetically differed significantly in all of the morphological characters measured (body mass, tarsus and wing length), with males being significantly larger than females. Although the discriminant rate varied substantially from one year to another, we found that it increased with the sample size of genetically sexed individuals. Our results suggest that discriminant function analysis (DFA) does not provide an efficient tool to sex greater flamingo chicks as these relationship are highly variable across years, requiring the genetic determination of sex on a large number of individuals every year for calibrating the DFA and still providing an overall low accuracy in sex determination. Indeed, conditions at breeding seasons can vary between years and can be considered proximate causes affecting the correct discriminant rate. Like previous studies, we recommend caution in dealing with discriminant equations computed from small datasets, and our simulation suggests that 325 genetically sexed individuals are needed to obtain $80 \%$ correctly classified greater flamingo chicks.
\end{abstract}

\section{Introduction}

The ability to correctly sex marked birds is crucial to most behavioral or ecological studies (Greenwood, 1980; Andersson, 1994; Short and Balaban, 1994; Childress and Bennun, 2002; Barbraud et al., 2003) and for the management and conservation of species (Zavalaga and Paredes, 1997; Fernandez-Juricic, et al., 2009). However, sex determination in immature and adult individuals where the plumage is similar in both sexes based only on external morphological characters is often difficult (Cuthill et al., 1999).

To overcome this difficulty a range of techniques have been used such as laparoscopy (Petrides, 1950; Richter and
Bourne, 1990; Richner, 1989), measuring the plasma testosterone levels during the breeding period (Czekala and Lasley, 1977; Bercovitz et al., 1978), vocalization analyses (Bourgeois et al., 2007), individual breeding or observation of territorial behavior (Castoro and Guhl, 1958; Flux and Innes, 2001; Fletcher and Hamer, 2003), and generalized molecular techniques (Griffiths et al., 1998; Bertault et al., 1999; Fridolfsson and Ellegren, 1999; Tomasulo et al., 2002; Dubiec and Zagalska-Neubauer, 2006; Balkız et al., 2007). However, despite the reliability and the large utilization of molecular techniques, these methods are time-consuming, intrusive and require extensive laboratory equipment, implying additional financial costs (Childress et al., 2005). 
Sexing based on morphological measurements using multivariate statistical approaches (e.g., discriminant function analysis, DFA) is often a reasonable choice for quick and inexpensive but efficient sex identification in field studies on bird species presenting monomorphic plumage (DechaumeMoncharmont et al., 2011). Indeed, the existence of a significant difference (even very small) between morphological measurements of males and females allows the discrimination between the sexes (Wilson, 1999; Donohue and Dufty, 2006; Moreno et al., 2007; Murphy, 2007; Ottvall and Gunnarsson, 2007; Cardoni et al., 2009). Diverse discriminant and logistic regression functions based on morphological measurements have been developed in many bird studies designed for widespread use by field researchers (Bosch, 1996; Balbontin et al., 2001; Bertellotti et al., 2002; Delvin et al., 2004; Figuerola et al., 2006, Hallgrimsson et al., 2011). However, different methods can be used to assess the reliability of these functions by examining the proportion of correctly classified males and females, such as, resubstitution (Zwarts et al., 1996; Copello et al., 2006), jackknife (O'Dwyer et al., 2006; Thorogood et al., 2009; Herring et al., 2008, 2010) or sample splitting methods (Setiawan et al., 2004; Meissner, 2005; Frey et al., 2008). Dechaume-Moncharmont et al. (2011) showed that the choice of the validation method may have a strong effect on the estimated discriminant rate, particularly for small sample sizes, and recommended the use of the jackknife method.

In this study, we used a large dataset (4013 birds measured across 11 years) of greater flamingo (Phoenicopterus roseus) chicks ringed and measured in the Camargue (southern France) and afterward sexed with molecular techniques (Bertault et al., 1999; Balkız et al., 2007). Greater flamingos lay a single egg and have a wide distribution, ranging from west Africa eastward throughout the Mediterranean to southwest and south Asia, and throughout sub-Saharan Africa (Johnson and Cézilly, 2007). Both sexes are similar in plumage but are sexually dimorphic in size when adults (Johnson and Cézilly, 2007). Although immature and adult male greater flamingos are significantly larger and heavier than females (Cramp and Simmons, 1977; Johnson et al., 1993), there remains a risk of error in sex determination based on size or weight due to the overlap of larger (and heavier) females with smaller (and lighter) males. This overlap is possibly wider in chicks, yet tarsus length of males appeared longer than that of females of exactly the same age in unfledged chicks from captivity (Studer-Thiersch, 1986).

The purposes of our study were to (1) examine whether DFA relying on morphological measurements of greater flamingo chicks predicts sex with a sufficient degree of accuracy, (2) test the applicability of one of the 11 single DFA formulas across cohorts and (3) evaluate through simulations the minimal sample size of chicks sexed by molecular methods to generate a DFA with a reliable discriminant rate.

\section{Material and methods}

As part of a long-term study on the reproductive biology of a colony of greater flamingos in Camargue, southern France $\left(43^{\circ} 25^{\prime} \mathrm{N}, 4^{\circ} 38^{\prime} \mathrm{E}\right)$, a proportion of chicks were captured at the end of each breeding season (end of July-early August) and banded with a metal ring and a unique combination of plastic bands that allowed recognition of individuals. For each chick, only three external measurements were made (body weight, tarsus length and wing length; Childress et al., 2005) to avoid prolonged capture stress. Thus, between 1995 and 2008 (except for 2001, 2002 and 2007), a total of 4013 Flamingos chicks were captured. A total of 1828 males and 2187 females were genetically sexed through PCR (polymerase chain reaction) amplification of the $C H D-Z$ and $C H D-W$ genes, using DNA extracted from blood or feather samples (Bertault et al., 1999, Balkız et al., 2007).

\subsection{Discriminant analysis functions}

For each cohort, we applied Box's $M$ test to verify the homogeneity of the variance-covariance matrix assumption before performing quadratic DFA in the case of violation of the assumption, otherwise linear DFA (Stevens, 1992) was used. These were conducted with the qda or lda function from the MASS package (Venables and Ripley, 2002) in R (version 3.6.1; R Development Core Team, 2019). To estimate the proportion of individuals with correctly classified sex (discriminant rate), we used the jackknife method (leave one out) (Manly, 1994): the sex of an individual is predicted from the DFA calculated after that individual has been taken out from the dataset. This procedure is repeated until a sex is assigned to each individual (Tabachnick and Fidell, 2000). Then, we examined whether the DFA for a given year could provide (or not) a reliable discriminant rate across cohorts. Finally, we used Student's $t$ test and Cohen's $d$ effect size to calculate the difference between mean male and female chicks external measurements.

\subsection{Effect of sample size}

We simulated the effect of sample size on the discriminant rate using the largest dataset available, i.e., 2006. We defined 133 different sample sizes regularly spaced every five individuals and ranging from 25 to 685 individuals. For each sample size, we used the jackknife method to simulate 500 different datasets by randomly sampling individuals (Table 1). We then calculated the mean DFA for each random dataset for a given sample size.

\section{Results}

\subsection{Sexual dimorphism}

We found significant differences in all morphological characters analyzed of genetically sexed greater flamingo chicks 


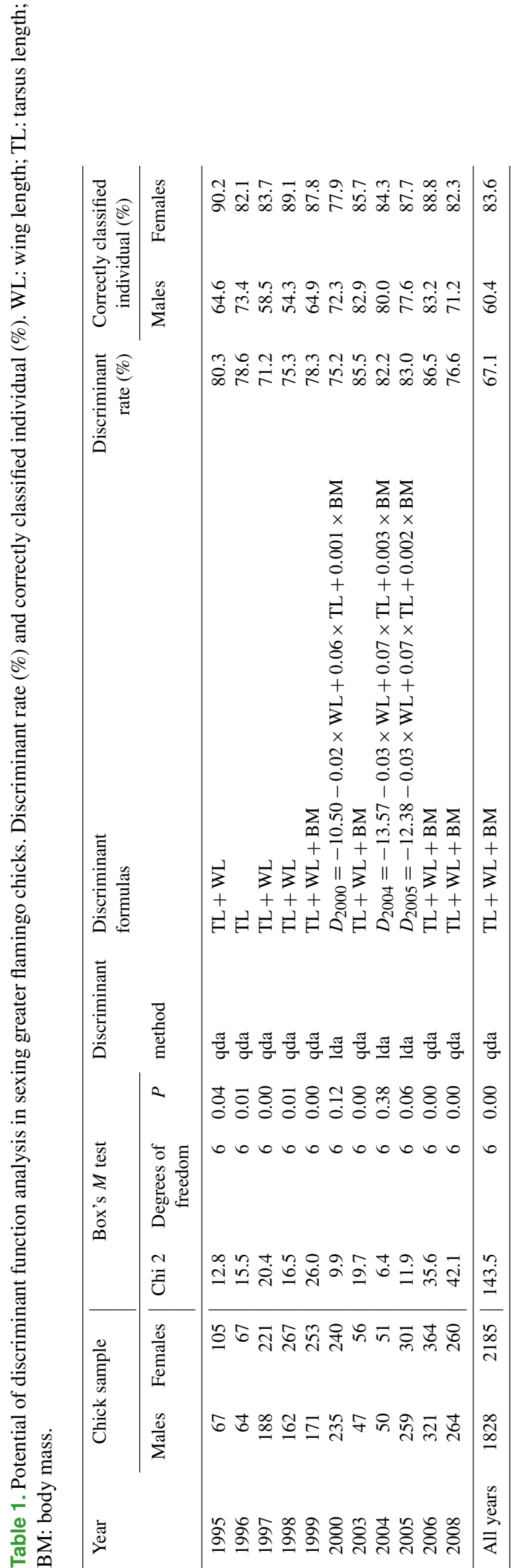

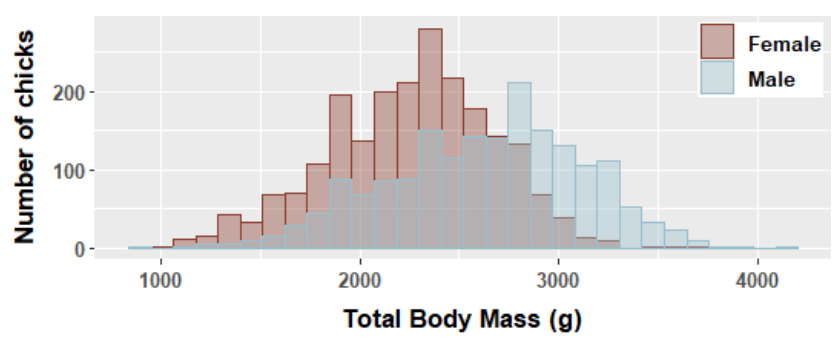
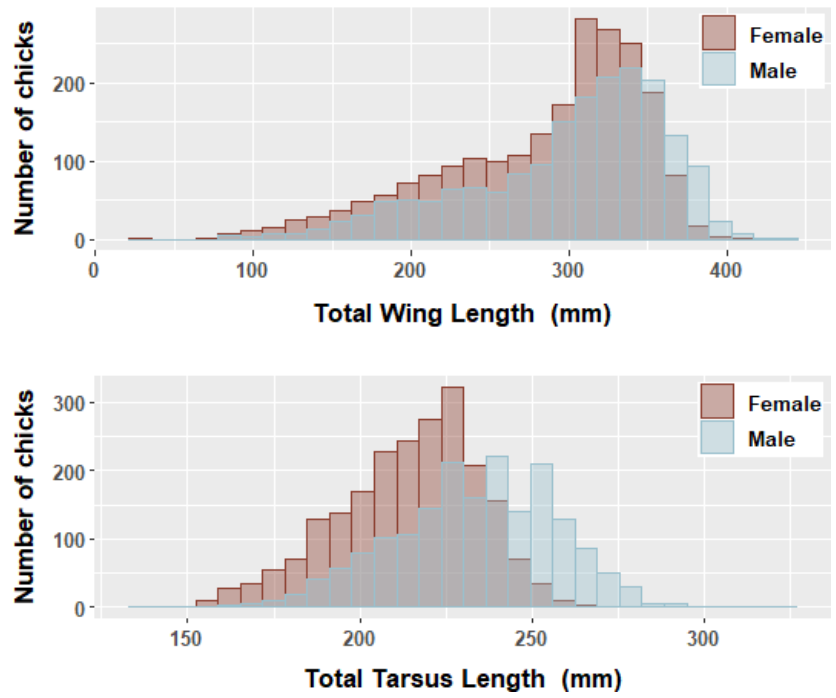

Figure 1. Mean (body mass, tarsus and wing length) of male and female greater flamingo chicks banded at Camargue, during 11 breeding seasons (1995-2008, except 2001, 2002 and 2007).

(males were larger than females $(t=33.7, p<0.000 * * *)$ ), and the mean difference index $(\mathrm{MDI}=100 \times$ mean female/mean male; Delestrade, 2001; Helfenstein et al., 2004) was $<95 \%$ for all characters (Table 2). Pooling all years, the largest difference occurred in body weight (males being 1.1 times heavier than females, Cohen's $d=0.8$ ). Dimorphism in tarsus length was also important for all years (ratio male $/$ female $=1.1$, Cohen's $d=0.9$ and was less important for wing length (ratio male / female $=1.0$, Cohen's $d=0.3$; Table 2; Fig. 1).

\subsection{Sex determination}

The discriminant rate of greater flamingo chicks using DFA was always $>70 \%$, yet varied substantially across cohorts (Table 1). Females were always better discriminated than males (Table 1). Evaluating whether one particular annual DFA could correctly predict sex across years showed major differences in the discriminant rate. For instance, the result found using the DFA of 2006 (the largest dataset) on the different cohorts led to a large difference of correct sex determination (from $52.4 \%$ in 2000 to $86.5 \%$ in 2006; Fig. 2), and the all-year function had the lowest discriminant rate (Table 1). 
Table 2. Comparisons between male and female greater flamingo chicks on Camargue (1995 to 2008, except 2001, 2002 and 2007) for three characters with mean difference index (MDI) calculated as (mean female / mean male) $\times 100$.

\begin{tabular}{lrrrrrr}
\hline Measurements & $\begin{array}{r}\text { Males } \\
(\text { mean } \pm \mathrm{SD})\end{array}$ & $\begin{array}{r}\text { Females } \\
(\text { mean } \pm \mathrm{SD})\end{array}$ & $\begin{array}{r}\text { Cohen’s } d \\
(95 \% \mathrm{CI})\end{array}$ & $\begin{array}{r}\text { MDI } \\
(\%)\end{array}$ & $t$ test & $P$ \\
\hline$N$ & 1828 & 2185 & & & & \\
Body mass $(\mathrm{g})$ & $2629.6 \pm 489.8$ & $2255.3 \pm 418.6$ & $0.8[0.8,0.9]$ & 85.8 & 26.1 & $0.000^{* * *}$ \\
Tarsus length $(\mathrm{mm})$ & $233.7 \pm 23.6$ & $214.4 \pm 20.8$ & $0.9[0.8,0.9]$ & 92.0 & 27.5 & $0.000^{* * *}$ \\
Wing length $(\mathrm{mm})$ & $300.5 \pm 62.9$ & $283.9 \pm 64.2$ & $0.3[0.2,0.3]$ & 94.5 & 8.3 & $0.000^{* * *}$ \\
\hline
\end{tabular}

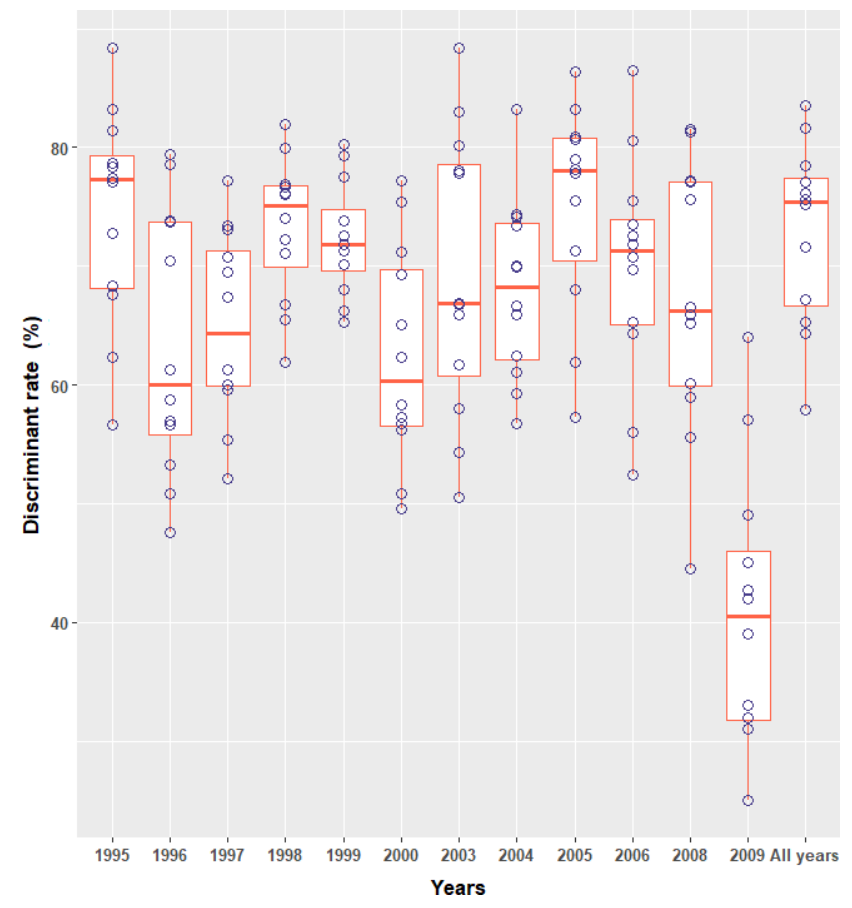

Figure 2. Boxplots of the yearly estimated discriminant rate (results of yearly DFA formulas validated on 11 different cohorts (19952008, except 2001, 2002 and 2007)).

\subsection{Sample size effect}

Obtained discriminant rates of correctly sexed greater flamingo chicks increased with increasing sample size. Indeed, the lowest DFA simulation results for samples of 50, 200 and 325 individuals were $58.0 \%, 76.6 \%$ and $80.0 \%$, respectively (Fig. 3).

\section{Discussion}

In the greater flamingos, as in many other birds, adult males are larger than females. However, sexing flamingo chicks remains difficult because flamingos continue to grow after fledging, and captures generally include individuals of different ages. Sexual dimorphism occurs in flamingos chicks with females of 1.5 to 2.5 months being already smaller than males of the same age (Studer-Thiersch, 1986; but see

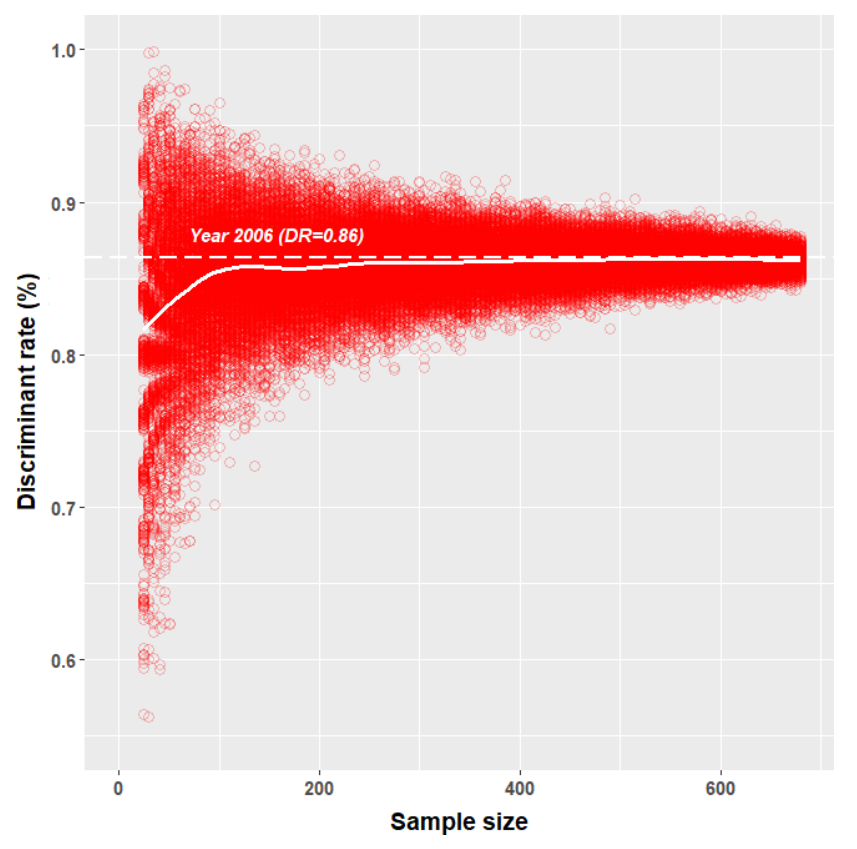

Figure 3. Simulation of the effect of sample size on the estimated proportion of correctly classified individuals (discriminant rate) in simulated discriminant function analyses (DFAs) of greater flamingo chicks from Camargue (France). From the largest dataset (year 2006, $n=685$ individuals), smaller subsamples were randomly selected (ranging from 25 to 685 individuals, with 500 subsamples per size). For each of these 66000 subsamples, we performed a DFA and evaluated the discriminant rate by jackknife cross-validation. Each red empty circle represents one DFA. The thick white line represents the mean discriminant rate computed from the 500 DFAs performed for each sample size. The dashed white line represents the DFA of the year 2006.

Bertault et al., 2000). Our results demonstrate that the sex of greater flamingo chicks can be determined based on individual morphology using DFA and a subsample of individuals molecularly sexed. This method was also used for adult greater flamingos (Richter and Bourne, 1990) and other birds, where morphometric criteria may discriminate between males and females (Childress et al., 2005; Alarcos et al., 2007; Hurley et al., 2007; Ackerman et al., 2008; Herring et al., 2008; Lislevand et al., 2009; Herring et al., 2010). 
However, we found that the reliability of one particular yearly discriminant function was reduced when attempting to apply it across cohorts. This result was consistent with the Evans et al. (1993) study on laughing gulls (Larus atricilla); they found a significant difference when DFA was applied at different years and localities. We also found that females were better discriminated than males in all years. The lower discriminant rate for males could result from an asymmetry in the distribution of the size of the males with an overrepresentation of smaller males. The discriminant rate of greater flamingo chicks varied from $67.1 \%$ to $86.5 \%$ and was lower than in other waterbird studies: Childress et al. (2005) on lesser flamingos Phonicopterus minor $(N=18$ individuals, $94.0 \%)$, Palomares et al. (1997) on black-headed gulls Larus ridibundus $(N=143,90.2 \%)$ and Herring et al. (2008) on great egrets Ardea alba $(N=76$, $89.5 \%$ ). Furthermore, our simulation showed that for small samples, there is a wide variance in the proportion of misclassified birds. Indeed, a high or low discriminant rate can be obtained by chance (low or high misclassified); therefore the use of a formula constructed from a small dataset is problematic in the greater flamingos and should be avoided. Like previous studies, we recommend extreme caution when sexing birds based on DFA, particularly when discriminant equations are derived from small datasets (Brennan et al., 1991; Shealer and Cleary, 2007; Isaksson et al., 2008; DechaumeMoncharmont et al., 2011). Our results show that sexing flamingo chicks based on DFA requires a large dataset and repeated sampling to include natural yearly variations on body condition during the breeding season. We therefore conclude that DFA is not an effective method to sex flamingo chicks.

Data availability. The data that support the findings of this study are available from the Tour du Valat greater flamingo team (bechet@tourduvalat.org), upon reasonable request.

Author contributions. AbB designed and conducted the study under the supervision of $\mathrm{AB}, \mathrm{RP}$ and $\mathrm{BS}$. AbB designed the statistical analyses and wrote the text. $\mathrm{AB}, \mathrm{RP}$ and $\mathrm{BS}$ supervised and commented on the text. RN, MG and FXDM commented on the text.

Competing interests. The authors declare that they have no conflict of interest.

Acknowledgements. We are most grateful to Ruben Heleno, Carolina Hospitaleche and the anonymous reviewer for their valuable comments. We are grateful to Luc Hoffmann and the Tour du Valat Foundation for material support.
Financial support. This work was financed by the MAVA foundation and the Algerian Ministère de l'Enseignement Supérieur et de la Recherche Scientifique (MESRS/DGRSTD). Abdennour Boucheker benefited from a PhD thesis grant from the MAVA foundation.

Review statement. This paper was edited by Ruben Heleno and reviewed by Carolina Hospitaleche and one anonymous referee.

\section{References}

Ackerman, J. T., Takekawa, J. Y., Bluso, J. D., Yee, J. L., and Eagles-Smith, C. A.: Gender identification of Caspian Terns using external morphology and discriminant function analysis, J. Field Ornithol., 120, 378-383, https://doi.org/10.1676/07-061.1, 2008.

Alarcos, S., De La Cruz, C., Solís, E., Valencia, J., and García-Baquero, M. J.: Sex determination of Iberian Azurewinged Magpies Cyanopica cyanus cooki by discriminant analysis of external measurements, Ringing Migr., 23, 211-216, https://doi.org/10.1080/03078698.2007.9674366, 2007.

Andersson, M.: Sexual selection, Princeton University Press, New Jersey, 1994.

Balbontin, J., Ferrer, M., and Casado, E.: Sex determination in Booted Eagles (Hieraaetus pennatus) using molecular procedures and discriminant function analysis, J. Raptor. Res., 35, 20 23, 2001

Balkız, Ö., Dano, S., Barbraud, C., Tekin, S., Özesmi, U., Dündar, M., and Béchet, A.: Sexing Greater Flamingos chicks from feather bulb DNA, Waterbirds, 30, 450-453, https://doi.org/10.1675/1524 4695(2007)030[0450:SGFCFF]2.0.CO;2, 2007.

Barbraud, C., Johnson, A. R., and Bertault, G.: Phenotypic correlates of post-fledging dispersal in a population of Greater Flamingos: the importance of body condition, J. Anim. Ecol., 72, 246257, https://doi.org/10.1046/j.1365-2656.2003.00695.x, 2003.

Bercovitz, A. B., Czekala, N. M., and Lasley, B. L.: A new method of sex determination in monomorphic birds, J. Zoo Anim. Med., 9, 114-124, https://doi.org/10.2307/20094391, 1978.

Bertault, G., Joulia, D., Johnson, A. R., and Raymond, M.: Sex determination in Greater Flamingos chicks through DNA analysis, Waterbirds, 22, 282-284, https://doi.org/10.2307/1522216, 1999.

Bertault, G., Raymond, M., Rousset, F., Cézilly, F., and Johnson, AR.: Evidence of seasonal sex ratio manipulation in the Greater Flamingos, Waterbirds, 23, 20-25, https://doi.org/10.2307/1522142, 2000.

Bertellotti, M., Tella, J. L., Godoy, J. A., Blanco, G., Forero, M. G., Donázar, J., and Ceballos, O.: Determining sex of Magellanic Penguins using molecular procedures and discriminant functions, Waterbirds, 25, 479-484, https://doi.org/10.1675/1524 4695(2002)025[0479:DSOMPU]2.0.CO;2, 2002.

Bosch, M.: Sexual size dimorphism and determination of sex in Yellow-legged Gulls, J. Field Ornithol., 67, 534-541, 1996.

Bourgeois, K., Curé, C., Legrand, J., Gómez-Díaz, E., Vidal, E. Aubin, T., and Mathevon, N.: Morphological versus acoustic analysis: what is the most efficient method for sexing yelk- 
ouan shearwaters Puffinus yelkouan?, J. Ornithol., 148, 261-269, https://doi.org/10.1007/s10336-007-0127-3, 2007.

Brennan, L. A., Buchanan, J. B., Schick, C. T., and Herman, S. G.: Estimating sex-ratios with discriminant function analysis: The influence of probability cutpoints and sample size, J. Field Ornithol., 62, 357-366, 1991.

Cardoni, D. A., Maldonado, J. E., Isacch, J., and Greenberg, R.: Subtle sexual dimorphism in the Bay-Capped Wren-Spinetail (Furnariidae) uncovered through molecular sex determination, Ornitol. Neotrop., 20, 347-355, 2009.

Castoro, P. L. and Guhl, A. M.: Pairing behavior of pigeons related to aggressiveness and territory, Wilson Bull., 70, 57-69, 1958.

Childress, B., Harper, D., Hughes, B., and Ferris, C.: Sex determination in the Lesser Flamingos (Phoenicopterus minor) using morphological measurements, Ostrich, 76, 148-153, https://doi.org/10.2989/00306520509485487, 2005.

Childress, R. B. and Bennun, L. A.: Sexual character intensity and its relationship to breeding timing, fecundity and mate choice in the Great Cormorant Phalacrocorax carbo lucidus, J. Avian Biol., 33, 23-30, https://doi.org/10.1034/j.1600048X.2002.330105.x, 2002.

Copello, S., Quintana, F., and Somoza, G.: Sex determination and sexual size-dimorphism in Southern Giant Petrels (Macronectes giganteus) from Patagonia, Argentina, Emu, 106, 141-146, https://doi.org/10.1071/MU05033, 2006.

Cramp, S. and Simmons, K. E. L.: Handbook of the Birds of Europe, the Middle East and North Africa, Oxford University Press, Oxford, 1977.

Cuthill, I. C., Bennett, A. T. D., Partridge, J. C., and Maier, E. J.: Plumage reflectance and the objective assessment of avian sexual dichromatism, Am. Nat., 153, 183-200, https://doi.org/10.1086/303160, 1999.

Czekala, N. M. and Lasley, B. L.: A technical note on sex determination in monomorphic birds using faecal steroid analysis, Int. Zoo Yearb., 17, 209-211, https://doi.org/10.1111/j.17481090.1977.tb00912.x, 1977.

Dechaume-Moncharmont, F. X., Monceau, K., and Cézilly, F.: Sexing birds using discriminant function: A critical appraisal, Auk, 128, 78-86, https://doi.org/10.1525/auk.2011.10129, 2011.

Delestrade, A.: Sexual size dimorphism and positive assortative mating in Alpine Choughs (Pyrrhocorax graculus), Auk, 118, 553-556, https://doi.org/10.1093/auk/118.2.553, 2001.

Delvin, C. M., Diamond, A. W., and Sauders, G. W.: Sexing Arctic Terns in the field and laboratory, Waterbirds, 27, 314-320, https://doi.org/10.1675/15244695(2004)027[0314:SATITF]2.0.CO;2, 2004.

Donohue, K. C. and Dufty, A. M.: Sex determination of Red-tailed Hawks (Buteo jamaicensis calurus) using DNA analysis and morphometrics, J. Field Ornithol., 77, 74-79, https://doi.org/10.1111/j.1557-9263.2006.00003.x, 2006

Dubiec, A. and Zagalska-Neubauer, M.: Molecular techniques for sex identification in birds, Biological Lett., 43, 3-12, 2006.

Evans, D. R., Hoopes, E. M., and Griffin, C. R.: Discriminating the sex of Laughing Gulls by linear mesurement, J. Field Ornithol., 64, 472-476, 1993.

Fernandez-Juricic, E., Del-Nevo, A. J., and Poston, R.: Identification of individual and population-level variation in vocalizations of the endangered Southwestern Willow Fly- catcher (Empidonax traillii extimus), Auk, 126, 89-99, https://doi.org/10.1525/auk.2009.07090, 2009.

Figuerola, J., García, L., Green, A. J., Ibanez, F., Manez, M., Valle, J. L. D., Garrido, H., Arroyo, J. L., and Rodríguez, R.: Sex determination in glossy ibis chicks based on morphological characters, Ardeola, 53, 229-235, 2006.

Fletcher, K. and Hamer, K.: Sexing terns using biometrics: the advantage of within-pair comparisons: Within-pair comparisons substantially improve the accuracy of sexing from biometrics for two congeneric species of seabird with monomorphic plumage and soft-tissue coloration, Bird Study, 50, 78-83, https://doi.org/10.1080/00063650309461294, 2003.

Flux, I. and Innes, J.: A field technique for determining the sex of North Island Kokako (Callaeas cinerea wilsoni), Notornis, 48, 217-223, 2001.

Frey, S. J., Rimmer, C. C., McFarland, K. P., and Menu, S.: Identification and sex determination of Bicknell's Thrushes using morphometric data, J. Field Ornithol., 79, 408-420, https://doi.org/10.1111/j.1557-9263.2008.00192.x, 2008.

Fridolfsson, A. K. and Ellegren, H.: A simple and universal method for molecular sexing of non-ratite birds, J. Avian Biol., 30, 116121, https://doi.org/10.2307/3677252, 1999.

Greenwood, P. J.: Mating systems, philopatry and dispersal in birds and mammals, Anim. Behav., 28, 1140-1162, https://doi.org/10.1016/S0003-3472(80)80103-5, 1980.

Griffiths, R., Double, M. C., Orr, K., and Dawson, R. J. G.: A DNA test to sex most birds, Mol. Ecol., 7, 1071-1075, https://doi.org/10.1046/j.1365-294x.1998.00389.x, 1998.

Hallgrimsson, G. T., Pálsson, S., and Summers, R. W.: Observations of bi-parental brood attendance and care in Purple Sandpipers Calidris maritima, Wader Study Group Bulletin, 118, 4546, 2011

Helfenstein, F., Danchin, E., and Wagner, R. H.: Assortative mating and sexual size dimorphism in Black-legged Kittiwakes, Waterbirds, 27, 350-354, https://doi.org/10.1675/1524 4695(2004)027[0350:AMASSD]2.0.CO;2, 2004.

Herring, G., Gawlik, D. E., and Beerens, J. M.: Sex determination for the Great Egret and White Ibis, Waterbirds, 31, 298-303, https://doi.org/10.1675/15244695(2008)31[298:SDFTGE]2.0.CO;2, 2008.

Herring, G., Ackerman, J. T., Eagles-Smith, C. A., and Takekawa, J. Y.: Sexing California Gulls using morphometrics and discriminant function analysis, Waterbirds, 33, 79-85, https://doi.org/10.1675/063.033.0109, 2010.

Hurley, V. G., Hogan, F., White, J., and Cooke, R.: A morphological model for sexing nestling Peregrine Falcons (Falco peregrinus macropus) verified through genetic analysis, Wildl. Res., 34, 5458, https://doi.org/10.1071/WR06059, 2007.

Isaksson, A., Wallman, M., Göransson, H., and Gustafsson, M. G.: Cross-validation and bootstrapping are unreliable in small sample classification, Pattern Recogn. Lett., 19, 1960-1965, https://doi.org/10.1016/j.patrec.2008.06.018, 2008.

Johnson, A. R. and Cézilly, F.: The Greater Flamingo, Poyser, London, 2007.

Johnson, A. R., Cézilly, F., and Boy, V.: Plumage development and maturation in the Greater Flamingos Phoenicopterus ruber roseus, Ardea, 81, 25-34, 1993.

Lislevand, T., Marthinsen, G., and Lifjeld, J. T.: Sex differences in body size and body condition in breeding Temminck's 
Stints Calidris temminckii, J. Field Ornithol., 150, 299-302, https://doi.org/10.1007/s10336-008-0323-9, 2009.

Manly, B. F. J.: Multivariate statistical methods: A Primer, Chapman and Hall, London, 1994.

Meissner, W.: Sex determination of juvenile Dunlins migrating through the Polish Baltic region, J. Field Ornithol., 76, 368-372, https://doi.org/10.1648/0273-8570-76.4.368, 2005.

Moreno, J., Merino, S., Lobato, E., Rodríguez-Gironés, M. A., and Vásquez, R. A.: Sexual dimorphism and parental roles in the Thorn-tailed Rayadito (Furnariidae), Condor, 109, 312-320, https://doi.org/10.1093/condor/109.2.312, 2007.

Murphy, M. T.: A cautionary tale: Cryptic sexual size dimorphism in a socially monogamous passerine, Auk, 124, 515-525, https://doi.org/10.1093/auk/124.2.515, 2007.

O'Dwyer, T. W., Priddel, D., Carlile, N., Bartle, J. A., and Buttemer, W. A.: An evaluation of three field techniques for sexing Gould's Petrels (Pterodroma leucoptera) (Procellariidae), Emu, 106, 245-252, https://doi.org/10.1071/MU05058, 2006.

Ottvall, R. and Gunnarsson, G.: Morphological and molecular sex identification of Redshanks Tringa totanus: Capsule Body measurements classified $81 \%$ of birds correctly to sex, Bird Study, 54, 127-129, https://doi.org/10.1080/00063650709461464, 2007.

Palomares, L. E., Arroyo, B. E., Marchamalo, J., Sainz, J. J., and Voslamber, B.: Sex- and age-related biometric variation of Black-headed Gulls Larus ridibundus in Western European populations, Bird Study, 44, 310-317, https://doi.org/10.1080/00063659709461066, 1997.

Petrides, G. A.: Notes on determination of sex and age in the Woodcock and Mourning Dove, Auk, 67, 357-360, https://doi.org/10.2307/4080924, 1950.

R Development Core Team: A Language and Environment for Statistical Computing, R Foundation for Statistical Computing, Vienna, 2019.

Richner, H.: Avian Laparoscopy as a field technique for sexing birds and anassessment of its effects on wild birds, J. Field Ornithol., 60, 137-142, 1989.

Richter, N. A. and Bourne, G. R.: Sexing Greater Flamingos by weight and linear measurements, Zoo Biol., 9, 317-323, https://doi.org/10.1002/zoo.1430090407, 1990.
Setiawan, A. N., Darby, J. T., and Lambert, D. M.: The use of morphometric measurements to sex Yellow-eyed Penguins, Waterbirds, 27, 96-101, https://doi.org/10.1675/15244695(2004)027[0096:TUOMMT]2.0.CO;2, 2004.

Shealer, D. A. and Cleary, C. M.: Sex determination of adult black terns by DNA and morphometrics: Tests of sample size, temporal stability and geographic specificity in the classification accuracy of discriminant function models, Waterbirds, 30, 180-188, https://doi.org/10.1675/15244695(2007)30[180:SDOABT]2.0.CO;2, 2007.

Short, R. V. and, Balaban, E.: The differences between the sexes, Cambridge University Press, Cambridge, 1994.

Stevens, J.: Applied Multivariate Statistics for the Social Sciences, edited by: Erlbaum, L., Hillsdale, New Jersey, 1992.

Studer-Thiersch, A.: Tarsus length as an indication of sex in the flamingo genus, Int. Zoo Yearb., 24, 240-243, https://doi.org/10.1111/j.1748-1090.1985.tb02546.x, 1986.

Tabachnick, B. G. and Fidell, L. S.: Using Multivariate Statistics, 4th edn., Harper Collins, New York, 2000.

Thorogood, R., Brunton, D., and Castro, I.: Simple techniques for sexing nestling Hihi (Notiomystis cincta), New Zeal. J. Zool., 36 , 115-121, https://doi.org/10.1080/03014220909510146, 2009.

Tomasulo, A. M., Del-Lama, S. N., and Rocha, C. D.: Molecular method of sexing waterbirds without DNA extraction, Waterbirds, 25, 245-248, https://doi.org/10.1675/15244695(2002)025[0245:MMOSWW]2.0.CO;2, 2002.

Venables, W. N. and Ripley, B. D.: Modern Applied Statistics with S, Springer-Verlag, Berlin, 2002.

Wilson, R. R.: Sex determination of the Acadian Flycatcher using discriminant analysis, J. Field Ornithol., 70, 514-519, 1999.

Zavalaga, C. B. and Paredes, R.: Sex determination of adult Humboldt Penguins using morphometric characters, J. Field Ornithol., 68, 102-112, 1997.

Zwarts, L., Hulscher, J. B., Koopman K., and Zegers, P. M.: Discriminating the sex of Oystercatchers Haematopus ostralegus, Ardea, 84, 1-12, 1996. 